\title{
Entrepreneurial Orientation and Knowledge Transfer: analysis in Spanish family businesses
}

\section{Orientación Emprendedora y Transferencia de Conocimiento: análisis en las empresas familiares españolas}

\author{
Ascensión Barroso-Martínez \\ University of Extremadura, Business Administration Department, Faculty of Economics, \\ Avda. Elvas, s/n 06006 Badajoz (Spain), abarrosom@unex.es \\ Ramón Sanguino-Galván \\ University of Extremadura, Business Administration Department, Faculty of Economics, \\ Avda. Elvas, s/n 06006 Badajoz (Spain), sanguino@unex.es \\ Tomas Manuel Bañegil-Palacios \\ University of Extremadura, Business Administration Department, Faculty of Economics, \\ Avda. Elvas, s/n 06006 Badajoz (Spain), tbanegil@unex.es
}

\begin{abstract}
This study tries to answer the following research questions in the context of family-owned firms: How is knowledge management related to entrepreneurship? How are knowledge management and entrepreneurship related to business performance? How does the family influence the above relationships? To answer these questions we performed a study to firms belonging to Family Business Regional Associations. The methodology used to analyze these relationships is based on a structural equation approach (SEM), specifically Partial Least Squares (PLS). The main value of this study is the proposition of two models. The first model analyzes the relationship among Knowledge Transfer (KT), Entrepreneurial Orientation (EO) and Performance (PERF). The second model studies the Family Influence (FI) as a moderating variable of such relationships. As conclusion, in these family firms KT has a significant positive effect on EO, and the latter on PERF. FI strengthening moderates the relationship between KT and EO and PERF. The implications for managers are clear. Our study provides a theoretical and empirical basis for further study on $\mathrm{KT}$ and EO in family business.
\end{abstract}

Keywords: entrepreneurship, entrepreneurial orientation, knowledge management, knowledge transfer, family firms, structural equation modeling.

\section{Resumen}

Este estudio trata de responder a las siguientes preguntas de investigación en el contexto de las empresas familiares: ¿Cómo se relaciona la gestión del conocimiento con el espíritu emprendedor? ¿Cómo se relacionan la gestión del conocimiento y el espíritu emprendedor con el rendimiento de la empresa? ¿Cómo influye la familia en dichas relaciones? Para responder a estas preguntas se realizó un estudio a las empresas que pertenecen a las Asociaciones Territoriales de Empresa Familiar. La metodología utilizada para analizar las relaciones propuestas se basa en un modelo de ecuaciones estructurales, concretamente el enfoque Partial Least Squares. El principal valor del trabajo es la propuesta de dos modelos: el primer modelo analiza la relación entre transferencia de conocimientos (TC), orientación emprendedora (OE) y rendimiento (REND); el segundo modelo estudia la influencia de la familia (IF) como una variable moderadora de dichas relaciones. Como conclusión, en las empresas familiares de nuestra muestra la TC tiene un efecto positivo significativo sobre la $\mathrm{OE}$, y ésta sobre el REND. La IF modera fortaleciendo la relación entre TC y OE y REND. Las implicaciones prácticas son claras. Nuestro estudio proporciona una base teórica y empírica para futuros estudios sobre TC y OE en las empresas familiares.

Palabras clave: espíritu emprendedor, orientación emprendedora, gestión del conocimiento, transferencia de conocimiento, empresa familiar, modelo de ecuaciones estructurales.

\section{Introduction}

The importance of family firms in the economy of a country is an indisputable fact, even more if the consequences of their business activities in the integral development of a society are analyzed (Basco, 2010). Studies in different countries have shown that family businesses play a key role in terms of economic growth and employment generation (Anderson \& Reeb, 2003). It is estimated that these kinds of companies account for 85 percent of all companies worldwide, 65 percent of the GDP and employment in Europe, and 50 percent of US GDP and 60 percent of its employment.

Research concerning the family firm has increased significantly in recent years. Some works try to explain the high death rate of family businesses (Lansberg \& Astrachan, 1994; Bañegil, Hernández \& Barriuso, 2012). One of the reasons of the failure of family businesses from the second generation is due to the lack of ability or willingness of the family involved in the succession process of creating, sharing and transferring knowledge from one generation to another (Chirico, 2008). Knowledge-based view suggests the importance of transferring the tacit knowledge, networking and social capital, passion and entrepreneurship in order to obtain competitive advantages. In fact, knowledge transfer is gaining increasing recognition by researchers because of its potential benefits both to individuals and organizations, and it is fundamental to the company success (Barroso, Sanguino \& Banegil, 2013). However, despite its importance, existing studies on knowledge management in family businesses are scarce (Mazzola, Marchisio \& Astrachan, 2008).

Moreover, to grow and survive in the current environment characterized by markets globalization, technological developments, advances in information and communication technology, it is necessary that founders' entrepreneurial behavior is transmitted to subsequent generations (Kellermans, Eddleston, Barnett \& Pearson, 2008). Consequently, entrepreneurship is also seen as an important 
element in the survival and growth of family firms. Nevertheless, it is necessary to develop more knowledge about the conditions under which family businesses are able to maintain and increase the transgenerational entrepreneurial behavior to survive and grow (Casillas, Moreno \& Barbero, 2010). It is essential to promote the entrepreneurial orientation through knowledge transfer to support the family businesses continuity, whose survival depends in part on the efforts made towards the formation of the whole set of people involved in the family firm.

On the basis of these arguments, this paper aims to test whether knowledge transfer influence entrepreneurial orientation and therefore performance. In this sense, this study tries to answer the research questions below: How is knowledge management related to entrepreneurship? How are knowledge management and entrepreneurship related to business performance? How does the family influence the above relationships?

The remainder of the paper is organized as follows. First, the theoretical background of the research is reviewed. Based on the literature review, the research model and hypotheses are developed. Next, the research methodology is described, and the results are analyzed. Finally, implications and limitations of the research are discussed, and future research directions are suggested.

\section{Theoretical Framework}

\subsection{Family firms}

Like any other, a family business strives to grow and generate income while maintaining business continuity. However, there is one important difference: the involvement of family (Vallejo, 2011). Family businesses are described as a system consisting of interacting sub-systems, which is depicted in two-circle model as family and enterprise (Gersik, Davis, Mccollom \& Lansberg, 1997). Due to the interaction of the two sub-systems (family and enterprise) the system family business emerges. This dual systems approach interprets the family as the intervening variable which has an effect on the firm and the firm's performance.

Regarding the concept of family business, it is a question posed that remains open after decades studying and researching family businesses (Astrachan, Klein \& Smyrnios, 2002), yet no clear consensus exists among the scientific community on what are the parameters that define the concept (Abdellatif, Amann \& Jaussaud, 2010). Although a wide variety of definitions can be found, most of the definitions include at least two dimensions: ownership and management or control. As regards the former, usually the majority company's capital is considered necessary (Lansberg, Perrow \& Rogolsky, 1988), but some researchers establish more restrictive limits (Brun de Pontet, Wrosch \& Gagne, 2007). Nonetheless, other definitions consider that family members have to legally own a percentage of ownership sufficient to control the company, does not require that this ownership percentage exceeds $50 \%$. On the other hand, the discussion on management is similar. Some researchers consider that to define a family business is necessary that the organization is managed by the family (Chua, Chrisman \&
Sharma, 1999). However, for others it is sufficient that one of the family members is part of the management team (Lansberg \& Astrachan, 1994).

Furthermore, although ownership and management are the criteria more used to conceptually define the term family business, some authors also use other criteria or dimensions such as the number of generations of the owning family (Davis, 1983), the influence of the family in the company (Chua, Chrisman \& Sharma, 1999), the continuity of company ownership by family member -transgenerational succession(Fahed-Sreih \& Djoundourian, 2006; Bañegil el al., 2012) or the existence of a strong sense of identity and a remarkable family culture in a the business (Pertusa \& Rienda, 2003). And even for others, it is the combination of the above dimensions (Barroso, Sanguino \& Bañegil, 2012).

\subsection{Knowledge transfer}

The growing importance that knowledge has acquired suggests the need to think about how organizations process their knowledge bases, that is, how organizations create and develop new knowledge, and how they share and transmit it (Hendriks, 1999; Wong \& Aspinwall, 2004). The success of many companies can be based on their ability to transfer the knowledge embodied in organizations and people which will provide the basis for the organizations' competitive advantage (Kumar \& Ganesh, 2009; Wong \& Aspinwall, 2004).Therefore, it is crucial to ensure performance and sustainable growth (Chirico, Sirmon, Sciascia \& Mazzola, 2011).Kumar and Ganesh (2009:163) define knowledge transfer as "a process of exchange of explicit or tacit knowledge between two agents, during which one agent purposefully receives and uses the knowledge provided by another." In family businesses context, knowledge transfer is the communication process from one generation to another or among the same generation (Barroso, Sanguino \& Bañegil, 2013).

In organizations members can learn from each other and benefit from new knowledge developed by others. Transferring knowledge provides opportunities for mutual learning and cooperation, which in turn stimulates the creation of new knowledge (Marouf, 2007). Similarly, in family firms knowledge transfer from one generation to another is important to manage the business efficiently; in turn, new generations have to add new knowledge and offer new perspectives to the family business. Just as it is necessary to share knowledge among different generations it is also necessary to share it among members of the same generation (Chirico, 2008). Within family businesses knowledge transfer should be easier than in other organizations. These firms have a common family language that allows them to communicate more efficiently and exchange more information in greater privacy (Hoffman, Hoelscher \& Sorenson, 2006). In addition, knowledge transfer often begins at the dining table, builds up during summer jobs at the company, and continues though a career at the family firm (Le Breton-Miller, Miller \& Steier, 2004). However, this facility to transfer knowledge is not always given in family businesses; since transfer is facilitated when there is a close relationship between family members as Barroso, Sanguino and Bañegil (2013) point out. 


\subsection{Entrepreneurial orientation}

A crucial aspect of entrepreneurship involves the recognition of emerging business opportunities, which are often exploited through the creation of new firms (Aldrich \& Cliff, 2003). Audretsch, Bönte \& Keilbach (2008) suggest that entrepreneurship is not only determined by the creation of new businesses, but also by the ability and willingness of innovative entrepreneurs to develop new products and processes based on new knowledge. Entrepreneurship is a useful concept that leads to companies on how to participate in the change and in the processes renewal in order to maintain and improve their competitiveness (Cruz, Habbershon, Nordqvist, Salvato \& Zellweger, 2006).

Entrepreneurial orientation is one of the most studied concepts in the literature of entrepreneurship, which focuses on decision-making styles, practices related to the entrepreneurial activity of business (Nordqvist, Habbershon \& Melin, 2008). One of the main authors who have studied entrepreneurship has been Miller (1983:771) which defines it as "one that engages in product market innovation, undertakes somewhat risky ventures, and is first to come up with proactive innovations, beating competitors to the punch". He suggests that the degree of entrepreneurship in a firm can be viewed as the extent to which it innovates, takes risks and acts proactively; being the main dimensions of entrepreneurial orientation. Although Lumpkin and Dess (1996) added two more dimensions (autonomy and competitive aggressiveness), in this paper we focus on Miller's dimensions because have been used in several studies (e.g. Casillas et al., 2010; Naldi, Nordqvist, Sjöberg \& Wiklund, 2007). These studies suggest that these scales of measurement are a viable tool for analyzing firm-level entrepreneurship (Wiklund, 2006).

Miller (1983) suggests that researchers should take into account the unique characteristics of different types of companies to study the firm-level entrepreneurship. Thus, the strength of entrepreneurship and the possible results may vary depending on the context of the enterprise, and the type, size, ownership and age of the company (Nordqvist et al., 2008). This leads us to think that family businesses are going to influence the force and results. Family firms constitute a unique context for entrepreneurship and to expand their knowledge to the next generations (Casillas et al., 2010), because they provide a particularly fertile ground for the essential entrepreneurial behavior that is needed for start-ups and growth (Aldrich \& Cliff, 2003).

\section{Hypotheses}

3.1 Knowledge transfer, entrepreneurial orientation, and performance

Transferring tacit knowledge is important to preserve and extend competitive advantage, since the success of a family business is often based on the unique experience of predecessors, being important to extend this experience to all the family firm members (Cabrera-Suárez, Saá-Pérez \& GarcíaAlmeida, 2001). An effective knowledge transfer is considered as the key to the organizational processes and outcomes, including the best practices transfer, new product development, speed learning and organizational survival (Zhang, Zheng, Li, Nie, Huo \& Shi, 2008). Moreover, it is important to know how and when family members are able to use their own knowledge and the knowledge acquired through its predecessors and other family members in order to increase their entrepreneurship, and in turn to convert them into positive outcomes (Chirico et al., 2011).Hence, we propose the following hypotheses:

$\mathbf{H}_{1}$ : Knowledge transfer positively influences entrepreneurial orientation.

$\mathbf{H}_{\mathbf{2}}$ : Knowledge transfer positively influences family firm performance.

$\mathbf{H}_{3}$ : Entrepreneurial orientation positively influences family firm performance.

\subsection{The interaction effect of family influence in knowledge} transfer, entrepreneurial orientation, and performance

In addition, the previous relationships might be moderated by family influence. Liu (2010) indicates that knowledge transfer is moderated by individual's cultural behavior and cognitive styles. In family firm context, knowledge transfer may be moderated by family's influence and behavior in the firm; as a result, entrepreneurial orientation and business performance will be affected by such moderated effect. Similarly, as said earlier, entrepreneurship may vary depending on the unique characteristics of the enterprise (Miller, 1983), and in our case of the family influence in the company (Nordqvist et al., 2008). Therefore, depending of the family influence companies more entrepreneurial than others can be found, influencing in turn in their performance (Kellermans et al., 2008; Naldi et al., 2007; Casillas et al., 2010). Thereby, we propose that family influence influences the above relationships. Formally:

$\mathbf{H}_{4}$ : Family influence moderatesstrengthening the relationship between knowledge transfer and entrepreneurial orientation.

$\mathbf{H}_{5}$ : Family influence moderates strengthening the relationship between knowledge transfer and performance.

$\mathbf{H}_{6}$ : Family influence moderatesstrengthening the relationship between entrepreneurial orientation and performance.

Figure 1 shows a synopsis of the above hypotheses; while in the first model (Model 1) the constructs is not strengthened through family influence (direct model), in Model 2 the impact of the constructs are potentially strengthened by the extent to which family influence exist (moderating model). 


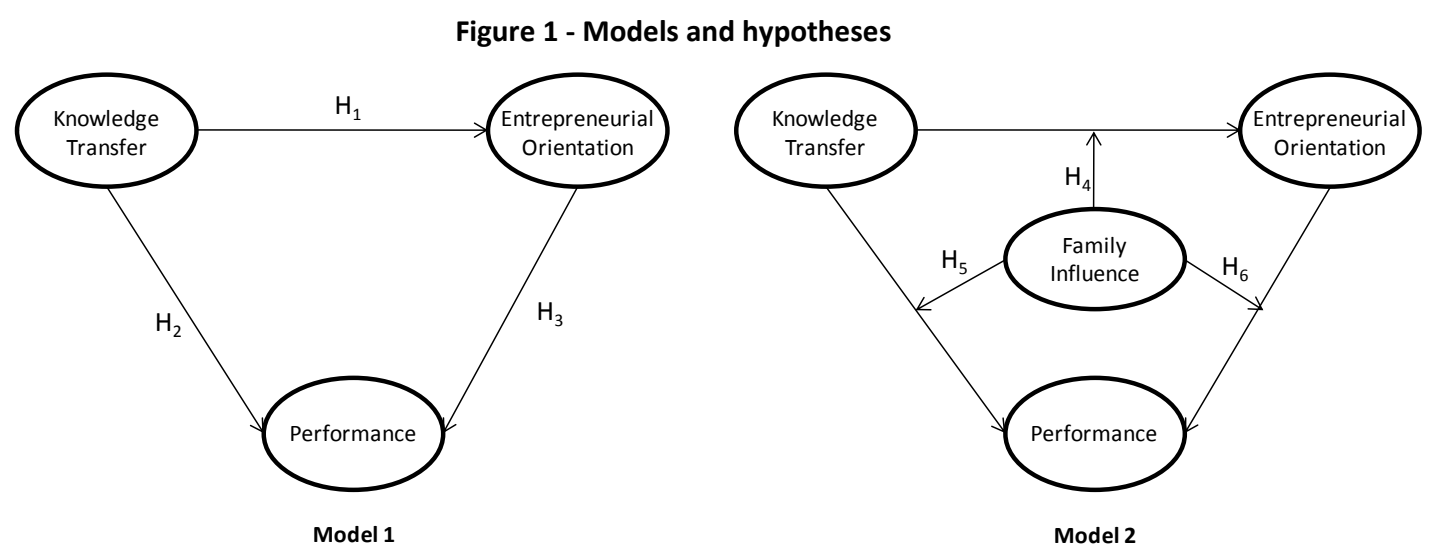

Source: authors

\section{Methodological approach}

\subsection{Procedures}

The population used in this study consists of Spanish firms associated to Family Business Regional Associations. In Spain there are 16 Associations with approximately 1100 family businesses in total. However, due to the data confidentiality, we only had information from 8 of them. A total of 480 family firms were identified from web pages of Associations and invited to participate. The information was collected via online survey. The collection of information took place over four months, from September to December 2012. The unit of analysis for the study was a successor of the firm, that is, a member of second or later generation. In total, 93 questionnaires were returned, yielding a response rate of $19.38 \%$. This is within the $10-20 \%$ range that is the average response rate for surveys involving senior management.

\subsection{Measures}

The study mainly used existing scales taken from the literature, where the items and responses appeared on a seven-point Likert scale ranging from "I completely disagree" to "I completely agree". The following constructs were used:

a) Knowledge Transfer (KT): this scale consists of five items based on the measurement scale from Bartol, Liu, Zeng and $\mathrm{Wu}$ (2009). This scale has been adapted to the specific context of family business to capture the degree to which the knowledge gained by a member of the company is easily transferred to another member of the firm. KT was modeled as reflective first-order construct.

b) Entrepreneurial orientation (EO): we relied on the nine-item scale developed by Miller (1983), which has dominated research on EO (also see Naldi et al., 2007; Chirico et al., 2011). We modeled EO as formative second-order construct, using three first-order dimensions: innovation (INNO), practiveness (PROAC) and risk taking (RISK).

c) Performance (PERF): was measured by asking respondents to compare the performance of their firm with the performance exhibited by their two main competitors in terms of profit, sales growth, cash flow, and growth of net worth. The scale has been validated in previous research (Wiklund,
2006; Naldi et al., 2007). PERF was modeled as reflective firstorder construct.

d) Family influence (FI): this construct measures if several generations are involved in the management, the generation in which the firms is, if the top management team is mainly formed by family member and if the family possesses the majority of company ownership. These four items are based on the scales used by Kellermans et al. (2008) and Casillas et al. (2010). Fl was modeled as formative first-order construct.

\subsection{Data analysis}

The questionnaire was validated simultaneously using partial least squares (PLS), a structural equation modeling (SEM) technique employing a principal-component-based estimation approach (Chin, 1998). PLS was selected because of the characteristics of our model and sample. Our model uses formative indicators and our data is non-normal. Other techniques of structural equation modeling (e.g. the covariance-based model performed by LISREL or AMOS) cannot be applied in these circumstances. For the hypothesis testing, we used the bootstrapping procedure recommended by Chin (1998).

This study uses SMART-PLS software Version 2.0.M3. Using PLS entails a two-stage approach (Chin, 2010). The first step requires the assessment of the measurement model. This allows the relationships between the observable variables and theoretical concepts to be specified. The analysis is performed in relation to the attributes of individual item reliability, construct reliability, average variance extracted (AVE) and the discriminant validity of the indicators of latent variables (Roldán \& Sanchez-Franco, 2012). In the second step, the structural model is evaluated. This is in order to test the extent to which the causal relationships specified by the proposed model are consistent with the available data (Cepeda-Carrión, Cegarra-Navarro \& Jiménez-Jiménez, 2012).

\section{Results}

\subsection{First step: Measurement model}

The measurement model for reflective constructs is assessed in terms of individual item reliability, construct reliability, convergent validity, and discriminant validity. In this respect, we would like to point out that the $\mathrm{FI}$ and EO variables are 
constructs specified with formative indicators. A latent variable with formative indicators implies that the construct is expressed as a function of the variables. The variables observed form, cause, or precede the construct. For this reason, traditional reliability and validity assessment have been argued as inappropriate and illogical (Roldán \& SanchezFranco, 2012).

Individual item reliability is considered adequate when an item has a factor loading that is greater than 0.7 on its respective construct. This is applicable to variables with reflective indicators (KT, INNO, PROAC, RISK, and PERF) (Table 1).
Notwithstanding, the assessment of formative measurement models at the indicator level is based on testing potential multicollinearity among items, as well as the analysis of weights. A high collinearity among indicators would produce unstable estimates and would make it difficult to separate the distinct effect of the individual manifest variables on the construct. Consequently, a collinearity test was performed using the SPSS program. Petter, Straub, and Rai (2007) indicate that a variance inflation factor (VIF) statistic greater than 3.3 signals a high multicollinearity. The maximum VIF value for our formative indicators was well below this threshold (Table 1).

Table 1 - Measurement model

\begin{tabular}{|c|c|c|c|c|c|c|c|}
\hline Construct/Indicator & VIF & Loading & Weight & t-statistic & CA & CR & AVE \\
\hline Knowledge Transfer (reflective) & & & & & 0,9255 & 0,9434 & 0,7693 \\
\hline KT1 & & 0,8716 & 0,2022 & 6,6565 & & & \\
\hline KT2 & & 0,9111 & 0,1954 & 5,7689 & & & \\
\hline KT3 & & 0,8491 & 0,2226 & 6,4600 & & & \\
\hline KT4 & & 0,9002 & 0,2296 & 9,8330 & & & \\
\hline KT5 & & 0,8516 & 0,2936 & 4,0405 & & & \\
\hline \multicolumn{5}{|c|}{ Entrepreneurial Orientation (second-order formative construct) } & n.a. & n.a. & n.a. \\
\hline Innovation (reflective) & 1,2817 & 0,7963 & $0,4985^{*}$ & 2,4881 & 0,7695 & 0,8647 & 0,6807 \\
\hline INNO1 & & 0,8132 & 0,4658 & 4,8448 & & & \\
\hline INNO2 & & 0,8576 & 0,4331 & 6,3564 & & & \\
\hline INNO3 & & 0,8034 & 0,3109 & 4,0379 & & & \\
\hline Proactiveness (reflective) & 1,3929 & 0,8833 & $0,7139 *$ & 3,9104 & 0,8620 & 0,9159 & 0,7841 \\
\hline PROAC1 & & 0,9112 & 0,3903 & 9,5231 & & & \\
\hline PROAC2 & & 0,8892 & 0,3604 & 7,6119 & & & \\
\hline PROAC3 & & 0,8552 & 0,3787 & 8,1049 & & & \\
\hline Risktaking (reflective) & 1,1294 & 0,1459 & $-0,1892$ & 1,0451 & 0,7829 & 0,8867 & 0,7978 \\
\hline RISK1 & & 0,9707 & 0,7690 & 2,4782 & & & \\
\hline RISK3 & & 0,8083 & 0,3136 & 1,2588 & & & \\
\hline Performance (reflective) & & & & & 0,7766 & 0,8558 & 0,5989 \\
\hline PERF1 & & 0,6904 & 0,2395 & 2,7140 & & & \\
\hline PERF2 & & 0,7362 & 0,3690 & 3,5362 & & & \\
\hline PERF3 & & 0,8388 & 0,3525 & 5,5111 & & & \\
\hline PERF4 & & 0,8206 & 0,3257 & 3,9202 & & & \\
\hline \multicolumn{8}{|l|}{ FamilyInfluence (formative) } \\
\hline F1 & 1,0162 & $-0,1685$ & $-0,2700$ & 0,7798 & n.a. & n.a. & n.a. \\
\hline F2 & 1,0185 & 0,4242 & 0,3527 & 0,9588 & & & \\
\hline F3 & 1,0683 & 0,8839 & $0,8108^{*}$ & 2,4594 & & & \\
\hline F4 & 1,0606 & 0,3864 & 0,2285 & 0,9201 & & & \\
\hline
\end{tabular}

Next, we assess the weights of the formative indicators. Weights provide information about how each formative indicator contributes to the respective composite construct (Chin, 1998). Hence, they allow us to rank indicators according to their contribution. Also, a significance level of at least 0.05 suggests that a formative measure is relevant for the construction of the composite latent construct. Consequently, we have checked the significance of the weights with a resampling procedure (bootstrap with 500 resamples) to obtain statistic values. We observe the presence of nonsignificant formative indicators in Table 1 . Nevertheless, we decide to keep these indicators because removing a formative indicator would imply the eliminating of a part of the composite latent construct.
The measures for construct reliability and convergent validity represent measures of internal consistency and, as discussed earlier, are only applicable for latent variables with reflective indicators. From an examination of the results, shown in Table 1 , we can state that all of the reflective constructs are reliable. Their values for both the Cronbach alpha (CA) coefficient and composite reliability (CR) are greater than the value of 0.7 required in the early stages of the research and the stricter value of 0.8 required for basic research. To assess convergent validity we examine the average variance extracted (AVE) measure. AVE values should be greater than 0.50 . Consistent with this suggestion, all our constructs exceed this condition (Table 1). To assess discriminant validity AVE should be greater than the variance shared between the construct and other 
constructs in the model (i.e., the squared correlation between two constructs). For adequate discriminant validity, the diagonal elements should be significantly greater than the offdiagonal elements in the corresponding rows and columns. This condition is satisfied for each reflective construct in relation to the rest of the variables (Table 2). For the variables with formative indicators we cannot analyze their situation because of the non-availability of AVE values.

Table 2 - Discriminant validity

\begin{tabular}{|l|l|l|l|l|l|}
\hline & INNO & KT & PERF & PROAC & RISK \\
\hline INNO & $\mathbf{0 , 8 2 5}$ & & & & \\
\hline KT & 0,440 & $\mathbf{0 , 8 7 7}$ & & & \\
\hline PERF & 0,284 & 0,229 & $\mathbf{0 , 7 7 4}$ & & \\
\hline PROAC & 0,467 & 0,439 & 0,380 & $\mathbf{0 , 8 8 5}$ & \\
\hline RISK & 0,190 & $-0,014$ & 0,099 & 0,336 & $\mathbf{0 , 8 9 3}$ \\
\hline
\end{tabular}

Diagonal elements (bold) are the square root of variance shared between the constructs and their measures (AVE). Off-diagonal elements are the correlations among constructs.

To assess the formative dimensions of second-order construct (EO), we similarly evaluate the multicollinearity among items and the weights. Results of the collinearity test show that the VIF scores of the second-order construct for all dimensions
(INNO, PROAC and RISK) are far below the commonly accepted cut-off of 3.3 (Table 1). Next, we assess their weights and significances. We also observe the presence of a nonsignificant formative indicator (RISK). Nevertheless, we decide to keep it because is a part of the entrepreneurial orientation construct.

\subsection{Second step: Structural model}

The evaluation of the structural model is based on the algebraic sign, magnitude and significance of the structural path coefficients, the R2 values (variance explained), and the Q2 (redundancy) test for predictive relevance (Roldán\& Sanchez-Franco, 2012).

Model 1 (Table 3) comprises the main three direct connections. In this case, whereas the relationship between knowledge transfer (KT) and performance (PERF) (H2) is not supported $(\beta 2=0,028$; $t$-value $=0,203$ ), the positive effect of KT on entrepreneurial orientation (EO) $(\mathrm{H} 1)$ is highly significant $(\beta 1=0,518 ; t$-value $=5,242)$. The other relationship between EO and PERF $(\mathrm{H} 3)$ is also significant $(\beta 3=0,383$; t-value $=$ 3,315).

Table 3. Structural models results

\begin{tabular}{|c|c|c|c|c|}
\hline \multirow[t]{2}{*}{ Relationships } & Model 1 & \multicolumn{2}{|c|}{ Model 2 with interaction effects } & \multirow{2}{*}{$\begin{array}{l}\text { Support } \\
F_{\text {EO }}^{2}=0,03 \\
F_{\text {PERF }}^{2}=0,07\end{array}$} \\
\hline & $\begin{array}{ll}\mathbf{R}_{\text {EO }}^{2}=0,347 & Q_{\text {EO }}^{2}=0,131 \\
R_{\text {PERF }}^{2}=0,157 & Q_{\text {PERF }}^{2}=0,088\end{array}$ & $\begin{array}{l}R_{E O^{\prime}}^{2}=0,366 \\
R_{\text {PERF' }}^{2}=0,209\end{array}$ & $\begin{array}{l}Q_{\text {EO' }}^{2}=0,321 \\
Q_{P E R F^{\prime}}^{2}=0,185\end{array}$ & \\
\hline $\mathrm{H}_{1}: \mathrm{KT} \rightarrow \mathrm{EO}$ & $0,518^{* * *}(5,242)$ & \multicolumn{2}{|c|}{$0,502 * * *(5,246)$} & Yes \\
\hline $\mathrm{H}_{2}: \mathrm{KT} \rightarrow \mathrm{PERF}$ & $0,028^{\text {ns }}(0,203)$ & \multicolumn{2}{|c|}{$0,022^{\text {n.s. }}(0,174)$} & Not \\
\hline $\mathrm{H}_{3}: \mathrm{EO} \rightarrow \mathrm{PERF}$ & $0,383^{* * *}(3,315)$ & \multicolumn{2}{|c|}{$0,387^{* *}(2,695)$} & Yes \\
\hline $\mathrm{H}_{4}: \mathrm{KT} \times \mathrm{FI} \rightarrow \mathrm{EO}$ & & \multicolumn{2}{|c|}{$0,140 * *(2,355)$} & Yes \\
\hline $\mathrm{H}_{5}: \mathrm{KT} \times \mathrm{FI} \rightarrow$ PERF & & \multicolumn{2}{|c|}{$0,272 * *(2,752)$} & Yes \\
\hline $\mathrm{H}_{6}: \mathrm{EO} \times \mathrm{FI} \rightarrow \mathrm{PERF}$ & & \multicolumn{2}{|c|}{$-0,129^{\text {n.s. }}(1,041)$} & Not \\
\hline
\end{tabular}

$* * * \mathrm{p}<0.001 ; * *<<0.01 ; * \mathrm{p}<0.05 i^{\text {ns }}$ : not significant (based on $\mathrm{t}(4999)$, one-tailed test)

$\mathrm{t}(0.05,4999)=1.645 ; \mathrm{t}(0.01,4999)=2.327 ; \mathrm{t}(0.001,4999)=3.092$

Indeed, the presence of three moderation hypotheses ( $\mathrm{H} 4, \mathrm{H} 5$ and $\mathrm{H6}$ ) on the links that form the direct effect of KT on EO, KT on PERF and EO on PERF, leads to the emergence of an interaction effect. This means such direct effects are dependent upon the value of the moderating variable family influence (FI). Consequently, we have to test the moderating effects.

Hypotheses 4, 5 and 6 have been tested using the Two-Stage PLS Approach. This technique is recommended by Henseler and Fassott (2010) for estimating moderating effects when formative constructs are involved. Whilst in the first stage the latent variable scores are estimated, these are used in the second stage to determine the coefficients of the regression function in the form of formula. Results show that the coefficients both of $\mathrm{KT} \times \mathrm{FI}$ EO $(\mathrm{H} 4)$, and $\mathrm{KT} \times \mathrm{FI}$ ? PERF $(\mathrm{H} 5)$ are statistically significant $(\beta 4=0,140$; $\mathrm{t}$-value $=2,355$ and $\beta 5=0,272$; $\mathrm{t}$-value $=$ 2,752, respectively) (Table 3, Model 2). However, the coefficient of EO $\times$ FI ? PERF $(\mathrm{H} 6)$ is not statistically significant and, even, has a negative effect $(\beta 6=-0,129 ; t$-value $=1,041)$.

On the other hand, the R2 values for Model 2 are compared to the R2 for the Model 1. The difference in R2 assesses the overall effect size $\mathrm{f} 2$ for each interaction effect. The effect size $\mathrm{f} 2$ can be calculated as $\mathrm{f} 2=$ (R2included - R2excluded $) /(1-$
R2included). Values of $0.02,0.15$ and 0.35 indicate the interaction term has a low, medium, or large effect on the criterion variable. It is important to understand that a low $\mathrm{f}_{2}$ does not necessarily imply an unimportant effect. If there is a likelihood of occurrence for the extreme moderating conditions and the resulting $\beta$ changes are meaningful, then it is important to take these situations into account (Hernández-Mogollón, Cepeda-Carrión, Cegarra-Navarro \& Leal-Millán, 2010). In our case, the results are shown in Table 3 . In model 1 (without interaction effect) the R2EO $=0,347$ and the R2PERF $=0,157$. The inclusion of interaction effect (model 2) shows an increase the R2 in both cases (R2EO' $=0,366$ and the R2PERF' $=0,209$ ). Consequently, the interaction terms achieve an $\mathrm{f} 2$ value of 0.03 (EO) and 0.07 (PERF), which in turn both represent a low effect.

Finally, we also evaluate the models with the cross-validated redundancy index (Q2) for the endogenous variables. Chin (2010) suggested this measure to examine the predictive relevance of the theoretical/structural model. A Q2 greater than 0 implies that the model has predictive relevance. Our results (table 3 ) confirm that both structural models have satisfactory predictive relevance for EO and PERF variables (Model 1: Q2EO = 0,131; Q2PERF = 0,088 and Model 2: Q2EO' = 0,$321 ;$ Q2PERF' $^{\prime}$ 0,185). 


\section{Figure 2 - Structural models results}

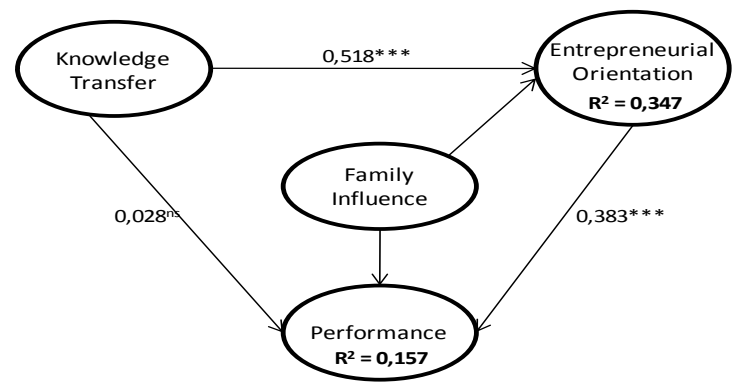

Model 1 without interaction effect

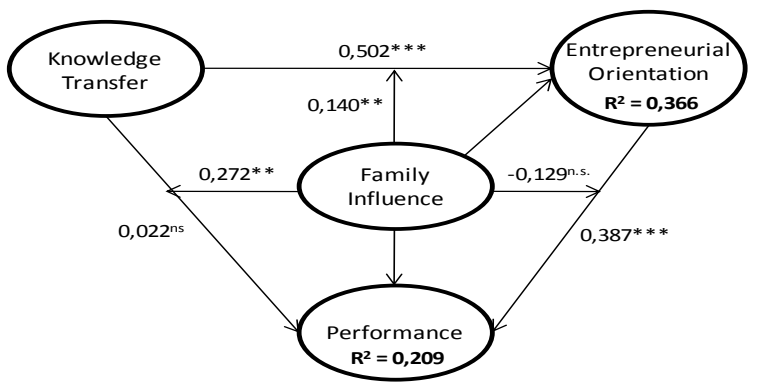

Model 2 with interaction effect

${ }^{* * *} p<0.001 ;{ }^{* *} p<0.01 ; * p<0.05 ;{ }^{\text {ns }}$ : not significant (based on $\mathrm{t}(4999)$, one-tailed.

\subsection{Discussion Model}

The purpose of this study has been to examine the relationships between knowledge management, entrepreneurship, performance and family influence. Accordant to our initial expectation, the empirical results of this study indicate that KT has a significant positive effect on EO (H1). Although many authors have studied empirically the effect of KT on EO, they have ignored investigate how company internal characteristics moderate this relationship. In our study, Fl strengthening moderates this relationship (H4).

The non-confirmation of $\mathrm{H} 2$ may be due to, in our case, companies value more the pursuing of non-economic or nonfinancial results. These results are mainly related to issues linked to the family, such as the desire to maintain control of the company in the hands of the family, family relationships, family dynasty, family lifestyle, company image identified with the family, and so on. These non-economic goals recently are known as socioemotional wealth. These assumptions are corroborated with the confirmation of $\mathrm{H} 5$, because when we introduce the family influence construct the relationship between KT and PREF is reinforced and significant.

Whilst the relationship between EO and PERF $(\mathrm{H} 3)$ is positive and significant as many studies demonstrate, the $\mathrm{FI}$ moderating effect in such a relationship (H6) is negative although not significant. These results may be due to family businesses have features that can restrict their entrepreneurial behavior as the aversion the risk, different perception of environment depending on the level of family generations involved, higher levels of ownership concentration, intentions to maintain family control of the business, and so on (Nordqvist et al., 2008; Kellermans et al., 2008).

\section{Conclusions, limitations and future research}

Our main conclusions are in line withthe last research and findings related with knowledge transfer in different contexts: Based on the knowledge transfer process interpretation, an analysis framework aimed at investigating the characteristics of knowledge transfer in the firm relationships (Albino, Garavelli \& Schiuma, 1999). Barriers and knowledge governance may provide a new understanding for organizations seeking effective knowledge transfer strategies in organizational context (Fang, Yang \& Hsu, 2013). The SME owners, rather than the employees, are the key source and the creators of knowledge and the sole drivers of the knowledge management processes (Wee \& Chua, 2013).

In this research we have focused on a different context, that is, to analyze how family businesses can promote behaviors, through relationships among its member, to transfer knowledge in order to improve their entrepreneurial orientation. Therefore, this research has determined that, although entrepreneurship depends on many factors at different organizational levels, the willingness of people to share their knowledge plays an important role in the entrepreneurial capacity. We conclude that the entrepreneurial orientation is explained by an extensive process of transferring knowledge among family members, who will contribute to the implementation of new ideas, processes, products or services.

There are various limitations to the study that warrant mention. First limitation is focused on the overall fit of the model, because although it is appropriate, we cannot forget that its explanatory power is limited to the variables involved in it. Second, only subjective information relating to the measurement of our different variables was solicited, therefore objective measure should be used to supplement subjective information. Finally, the study was carried out in a particular inter-firm network (Family Business Associations). We must therefore be cautious about generalizing the results to other family firms.

Future research needs to continue to develop a better understanding about family influence among the variables studied in this paper. Several researchers note that family businesses have higher entrepreneurial orientation in the founder stage, and this orientation decreases as the next generations are involved in the company (Kellermans et al., 2008). Other studies show that family businesses in second generation or multigenerational show greater entrepreneurial behavior than family businesses in first generation (Casillas et al., 2010). Thereby, it would be interesting to disaggregate the family influence construct and to perform multigroups with the four items that making up this construct.

\section{References}

Abdellatif, M., Amann, B. \& Jaussaud, J. (2010). Family versus nonfamily business: a comparison of international strategies. Journal of Family Business Strategy, 1(2), 108-116. 
Albino, V., Garavelli, C.\&Schiuma, G. (1999).Knowledge transfer and inter-firm relationships in industrial districts: the role of the leader firm. Technovation, 19, 53-63.

Aldrich, H. \& Cliff, J. (2003). The pervasive effects of family on entrepreneurship: toward a family embeddedness perspective. Journal of Business Venturing, 18 (5), 573-596.

Anderson, R. C. \& Reeb, D. M. (2003). Founding-family ownership and firm performance: evidence from the S\&P 500. The Journal of Finance, 58 (3), 1301-1328.

Astrachan, J. H., Klein, S. B. \& Smyrnios, K. X. (2002). The F-PEC scale of family influence: a proposal for solving the family business definition problem. Family Business Review, 15(1), 45-58.

Audretsch, D., Bönte, W. \& Keilbach, M. (2008). Entrepreneurship capital and its impact on knowledge diffusion and economic performance. Journal and Business Venturing, 23(6), 687-698.

Bañegil, T. M., Hernández, R., \& Barriuso, C. (2012). El Protocolo Familiar y Sus Instrumentos de Desarrollo en las Empresas Familiares de Extremadura. Tourism \& Management Studies, (8), 139-150.

Barroso, A., Sanguino, R. \&Bañegil, T. M. (2013). Study of factors influencing knowledge transfer in family firms. Intangible Capital, 9(4), 1216-1238.

Barroso, A., Sanguino, R. \& Bañegil, T. M. (2012). Diferentes criterios del concepto de empresa familiar. Una aportación desde Extremadura, España. Ide@sConcyteg, 83(7), 611-622.

Bartol, K. M., Liu, W., Zeng, X. \& Wu, K. (2009).Social exchange and knowledge sharing among knowledge workers: the moderating role of perceived job security. Management and Organizational Review, 5 (2), 223-240.

Basco, R. (2010). Tipo de orientación familiar y prácticas de dirección y gobierno. Un estudio aplicado a las empresas familiares españolas. Revista Europea de Dirección y Economía de la Empresa, 19(2), 129144.

Brun de Pontet, S., Wrosch, C. \& Gagne, M. (2007). An exploration of the generational differences in levels of control held among family business approaching succession. Family Business Review, 20(4), 337354.

Cabrera-Suárez, K.,Saá-Pérez, P. \& García-Almeida, D. (2001). The succession process from a resource-and knowledge-based view of the family firm. Family Business Review, 14(1), 37-48.

Casillas, J., Moreno, A. \&Barbero, J. (2010). A configurational approach of the relationship between entrepreneurial orientation and growth of family firms. Family Business Review, 23(1), 27-44.

Cepeda-Carrión, G., Cegarra-Navarro, J.G. \& Jimenez-Jimenez, D. (2012). The effect of absorptive capacity on innovativeness: context and information systems capability as catalysts. British Journal of Management, 23(1), 110-129.

Chin, W.W. (1998). The partial least squares approach to structural equation modeling. In G. A. Marcoulides (Ed.), Modern methods for business research (pp. 295-336). Mahwah, NJ: Lawrence Erlbaum.

Chin, W.W. (2010). How to write up and report PLS analyses. In V. Esposito Vinzi, W.W. Chin, J. Henseler, et al. (Eds), Handbook of partial least squares: concepts, methods and applications (pp. 655-690). Berlin: Springer-Verlag.

Chirico, F. (2008). Knowledge accumulation in family firms: evidence from four cases studies. International Small Business Journal, 26(4), 433-462.

Chirico, F., Sirmon, D. G., Sciascia, S. \& Mazzola, P. (2011). Resource orchestration in family firms: investigating how entrepreneurial orientation, general involvement and participative strategy affect performance. Strategic Entrepreneurship Journal, 5(4), 307-326.

Chua, J. H., Chrisman, J. J. \& Sharma, P. (1999). Defining the family business by behavior. Entrepreneurship Theory and Practice, 23, 19-39. Cruz, C., Habbershon, T., Nordqvist, M., Salvato, C. \& Zellweger, T. (2006). A conceptual model of transgenerational entrepreneurship in family-influenced firms. Jväskilä: International Family Enterprise Research Academy.

Davis, P. (1983). Realizing the potential of the family business. Organizational Dynamics, 12(1), 47-56.
Fahed-Sreih, J. \& Djoundourian, S. (2006). Determinants of longevity and success in Lebanese family business: an exploratory study. Family Business Review, 19(3), 225-234.

Fang, S., Yang, C. \& Hsu, W. (2013). Inter-organizational knowledge transfer: the perspective of knowledge governance. Journal of Knowledge Management, 17(6), 943-957.

Gersik, K., Davis, J. Mccollom, H. \& Lansberg, I. (1997). Generation to generation: life cycles of the family business. Boston: Harvard Business School Press.

Hendriks, P. (1999). Why share knowledge? The influence of ICT on the motivation for knowledge sharing. Knowledge and Process Management, 6(2), 91-100.

Henseler, J. \& Fassott, G. (2010).Testing moderating effects in PLS path models: an illustration of available procedures. In J. E. Gentle, W. K. Härdle\& Y. Mori (Eds.), Springer Handbooks of Computational Statistics (pp. 713-735). Berlin, Heidelberg: Springer.

Hernández-Mogollón, R., Cepeda-Carrión, G., Cegarra-Navarro, J.G. \& Leal-Millán, A. (2010).The role of cultural barriers in the relationship between open-mindedness and organizational innovation. Journal of Organizational Change Management, 23(4),360 - 376.

Hoffman, J., Hoelscher, M. \& Sorenson, R. (2006). Achieving sustained competitive advantage: a family capital theory. Family Business Review, 19(2), 135-145.

Kellermans, F., Eddleston, K., Barnett, T. \& Pearson, A. (2008). An exploratory study of family member characteristics and involvement: effects on entrepreneurial behavior in the family firm. Family Business Review, 21(1), 1-14.

Kumar, J. A. \& Ganesh, L. S. (2009). Research on knowledge transfer in organizations: a morphology. Journal of Knowledge Management, 13(4), 161-174.

Lansberg, I. \& Astrachan, J. H. (1994). Influence of family relationships on succession planning and training: the importance of mediating factors. Family Business Review, 7(1), 39-59.

Lansberg, I. S., Perrow, E. L. \& Rogolsky, S. (1988). Family business as an emerging field. Family Business Review, 1, 1-8.

Le Breton-Miller, I., Miller, D. \& Steier, L. P. (2004). Toward an integrative model of effective $\mathrm{FOB}$ succession. Entrepreneurship Theory and Practice, 28 (4), 305-328.

Liu, J (2010). Culture and knowledge transfer: theoretical considerations. Journal of Service Science and Management, 3, 159164.

Lumpkin, G. \& Dess, G. (1996). Clarifying the entrepreneurial orientation construct and linking it to performance. Academic of Management Review, 21(1), 135-172.

Marouf, L. N. (2007). Social networks and knowledge sharing in organizations: a case study. Journal of Knowledge Management, 11(6), 110-125

Mazzola, P., Marchisio, G. \& Astrachan, J. (2008). Strategic planning in family business: a powerful developmental tool for the next generation. Family Business Review, 21, 239-258.

Miller, D. (1983). The correlates of entrepreneurship in three types of firms. Management Science, 29(7), 770-791.

Naldi, L., Nordqvist, M., Sjöberg, K. \& Wiklund, J. (2007). Entrepreneurial orientation, risk taking and performance in family firms. Family Business Review, 20(1), 33-47.

Nordqvist, M., Habbershon, T. G. \& Melin, L. (2008). Transgenerational entrepreneurship: exploring entrepreneurial orientation in family firms. In H. Landström, D. Smallbone, H. Crijns \& E. Laveren (Eds.), Entrepreneurship, sustainable growth and performance: frontiers in European entrepreneurship research (pp. 93-116). London: Edward Elgar.

Pertusa, O. \& Rienda, L. (2003). Las relaciones de agencia y la gestión de la empresa familiar: revision teórica de su eficacia y eficiencia frente a empresas no familiares. Revista de Economía y Empresa, 49, 67-77.

Petter, S., Straub, D. \& Rai, A. (2007). Specifying formative constructs in information systems research. MIS Quaterly, 34(4), 623-656.

Roldán, J. L. \& Sánchez-Franco, M. J. (2012). Variance-based structural equation modelling: guidelines for using partial least squares in 
information systems research. In Mora, M., Gelman, O., Steenkamp, A., \& Raisinghani, M.S. (Eds.) Research methodologies, innovations and philosophies in software systems engineering and information systems (pp.193-221). Hershey, PA: IGI Global.

Vallejo, M. C. (2011). A model to study the organizational culture of the family firm. Small Business Economics, 36(1), 47-64.

Wee; J. \& Chua, W. (2013). The peculiarities of knowledge management processes in SMEs: the case of Singapore. Journal of Knowledge Management, 17(6), 958-972.

Wiklund, J. (2006). The sustainability of the entrepreneurial orientation-performance relationship. In P.Davidsoon, F. Delmar \& J.Wiklund (Eds), Entrepreneurship and the growth of firms (pp. 141155). Camberley Surrey, UK: Edward Elgar.

Wong, K. Y. \& Aspinwall, E. (2004). Characterizing knowledge management in the small business environment. Journal of Knowledge Management, 8(3), 44-61.

Zhang, L., Zheng, X., Li, J., Nie, G., Huo, G. \& Shi, Y. (2008). A way to improve knowledge sharing: from the perspective of knowledge potential. Journal of Service Science and Management, 1, 226-232.

\section{Article history:}

Submitted: 13.12 .2014

Received in revised form: 18.04 .2015

Accepted: 27.04.2015 